\title{
The Development of College English Education under the Background of "the Belt and Road Initiative"
}

\author{
Hongtu Ren \\ Feixian Campus, Linyi University, China \\ 435995789@qq.com
}

\begin{abstract}
Keywords: Globalization; The Belt and road initiative; College English education; Cultural communication; Cross-cultural consciousness
\end{abstract}

\begin{abstract}
With the development of economic globalization, China put forward "the Belt and Road Initiative" creatively according to the current international situation. Under the background of globalization, in addition to promoting the economic development of the countries along the routes, cultural exchange is an important part of "the Belt and Road Initiative". With the growing international communication, as a international language, English is playing an more and more important role. Colleges are the base of talents cultivation and English has become a compulsory course of the contemporary college students. Education should keep pace with the times, it will be difficult to adapt to the society's needs if it can't gear to the development of the times. We should make English play an instrumental role instead of being an armchair strategist.
\end{abstract}

\section{Introduction}

"The Belt and Road Initiative" has became a hot topic as soon as it was put forward. We have to refer to the Silk Road when we mention "the Belt and Road Initiative". New Silk Road formed a new concept on the basis of the old Silk Road. Its primary objective is to promote the economic development and cultural exchanges between China and involved countries. Cultural exchange is also one of the important connotation under the background of the economic exchange. English has become one of the compulsory course in contemporary college education system. With the growing international communication, as a communication tool, English should play a bridging role under the background of "the Belt and Road Initiative". Because of the influence of traditional education system, college English has many limitations not only in teachers' teaching but also in students' learning. College English Test is a main form of assessment, but it's difficult to achieve the goal of assessment scientifically. Therefore, the reform of English teaching is imperative in order to promote English to play its due role .In addition to add English skills training, such as speaking and listening and so on, We should add cross-cultural teaching content to enrich students' knowledge, improve their English, and lay the foundation for the development of "the Belt and Road Initiative".

\section{Overview of "the Belt and Road Initiative"}

China has a long history and culture. The Silk Road which has experienced the vicissitudes of more than 2000 years is not only a cultural treasure of Chinese history but also a precious legacy of the cultural history of the world. Traditional meaning of Silk Road is the old Silk Road. The Silk Road has become a culture system containing economy politics and religion after thousands of years' development[1].

March 27, 2015 in Hainan Boao forum for Asia, Chinese National Development and Reform Commission, the Ministry of Foreign Affairs and the Ministry of Commerce jointly issued the "Push to build Silk Road Economic Belt and twenty-first Century Maritime Silk Road vision and action". This marks that "the Belt and Road Initiative" entered the construction phase. This concept of peaceful development has been recognized by the whole world. In the past three years, it has attracted more than 100 countries and international organizations to participate. "The Belt and Road Initiative" was based on the multilateral mechanisms between China and the involved countries. It draws on the experience of the old Silk Road, adheres to the banner of peaceful development and 
actively develop multilateral trade cultural exchange with the countries along the routes to form a cooperative and inclusive community of interests and contribute to the peaceful development of the world.

\section{Content of Cross-Cultural Concept of the College English}

The development of "the Belt and Road Initiative" will certainly further propel the trend of globalization, therefore, the importance of English is highlighted out again. Because of the influence of traditional test-oriented education, although college English teaching has changed a lot compared with the high school, many times it still stresses the importance of tests. As a main form of assessment, College English Test can scientifically evaluate students' English level over a period of time, but with the development of the society, college students' poor communicative competence has become a common social phenomenon. With the development of "the Belt and Road Initiative", the speaking and listening abilities of English are more important. Therefore, college English education must be reformed in order to adapt to the social development and meet the need of communication between countries under the economic globalization.

English teaching in college is different from middle and high school. Although the main learning objective is not to take the test, the students will still be influenced by the traditional teaching concepts. Especially for English majors, most of them will engage in the jobs related to English after graduation. Therefore, the college English teaching should highlight the practicability of English. All these require English teachers to strengthen the cultural guidance to the students and make them fully understand and grasp culture connotations of English speaking countries. Today, with globalization gradually penetrating, the communication between China and English speaking countries is more and more frequent. As an international language, English has prominent position in the international communication. Seen from the scope of English communication, it is not only limited to the past international trade but involves each social professions and the domains. Language is the carrier of culture, communication between the countries will be extremely difficult without the bridging role of language. English study is not only a language study but also cultural study, it has strong geographic feature and national identity. Studying English must be based on understanding each others' cultural background for college students, therefore, it is necessary to add cross-cultural content to college English education[2]. As knowledge imparters, teachers should understand more about English culture in order to improve English teaching efficiency and carry out college English teaching in practice.

\section{Analysis on the Development of College English Education under the Background of "the Belt and Road Initiative"}

Emphasizing the Synchronization of Foreign Culture and Native Culture. Firstly, in order to achieve the organic integration of language and culture, teachers should emphasize the proper guidance of multiculture instead of imbuing foreign culture in the teaching process. With the development of new teaching reform, we should not only emphasize the students as the main body in college classroom but also cannot neglect the teachers' guiding role. The teachers not only need to imbue teaching ideas and knowledge system but teach the students learning methods. Under the background of "the Belt and Road Initiative", the reform of college English teaching requires the teachers to integrate the multiculture into every link of English teaching and arrange various forms of linguistic and cultural activities so as to improve the college students' literacy.

Secondly, the teachers should penetrate the multicultural education ideas and further renew the way of cultural spread. Language is the bridge of cultural communication and culture is the embodiment of the value of language communication in return. The college English teaching goal is not only to learn language knowledge but also penetrate the multicultural education ideas consciously and purposely in the process of language study. We should further achieve innovative development of college English cultural teaching on the basis of continuing traditional language teaching ideas. The multicultural theory inculcation is a huge job and can't be achieved overnight. 
The teachers should teach western and native culture at the same time, this will help students form correct cultural concept[3]. The exchanges and collisions between different cultures can motivate students' study enthusiasm and creativity and make students sum up the rules of language learning by themselves and improve their English.

Creating a Cultural Characteristics System. Firstly, the teachers should define teaching aim of English culture and further innovate the teaching model of college English. To make college English teaching better adapt to the development of times, integrating diversified strategy in the teaching process has become core, it is also the crux to achieve college English teaching task. The construction of teaching strategy is on the basis of teaching aim. Reasonable teaching aim can make college English teaching construct teaching system perfectly. Thus setting teaching aim must accord with the law of contemporary college students' development. In addition to considering language learning goal, setting the college English teaching aim should add the content of expanding cultural education and make students further understand the way of communication between humans in English context and improve their communicative competence by cultivating the students' cultural literacy. Only defining English cultural teaching aim can improve the students' learning ability and help to optimize and develop the college English teaching model. The teachers should introduce the differences between different cultures, especially under the background of "the Belt and Road Initiative", they should introduce more local customs and culture of the countries alone the routes to enhance the students' cultural acuity.

Secondly, the teachers should further widen English teaching channels and expand the resources of English cultural course. A integrated teaching is a very complicated teaching activity, teacher, students and textbook are not only participants of English teaching activities but also very important teaching resources. Adjusting the way of their participation in teaching activities according to the actual teaching situation can help achieve the diversity of teaching resources. In addition to learning textbook, the teachers can provide English movies, songs and other teaching resources for the students by searching on the internet, guide the students to correctly understand western culture history and social customs. Furthermore, with the development of science and technology, multimedia teaching has been widely used in college teaching. The teachers can make use of multimedia devices to fuse image data and English language knowledge and make courseware which is fit for students' learning habits. This can enrich the forms of language learning and realize real-time interaction between language and culture.

Forming Scientific College English Cultural Evaluation Mechanism. Firstly, we should contact with western culture selectively and cultivate cultural inclusive consciousness. Under the background of "the Belt and Road Initiative", we repeatedly stress the importance of cultivating intercultural consciousness in college English teaching. Cultural knowledge imbuing doesn't require language learners to pursue the culture blindly, but define the independence of our own culture and contact with western culture selectively. We should set up correct cultural selection model when we have cultural inclusive consciousness[4]. With the further improvement of college English teaching system, we should further emphasize the way of cultural exchanges and guide the students scientifically to face the difference between different cultures correctly.

Secondly, we should further innovate the traditional English evaluation mechanism. For the college students, College English Test is the most important except the daily final exam. But College English Test lacks of the assessment of oral English capability. Some students who have poor listening ability can pass the College English Test by improving their reading and composition scores. With the development of globalization, college should further make perfect evaluation mechanism and achieve dynamic assessment to the students' English ability.

\section{Conclusion}

Under the background of "the Belt and Road Initiative", the impact of globalization on society is further deepened. So it is very important to cultivate the students' cross-cultural consciousness in college English teaching and has great practical significance. Adding cross-cultural teaching content to college English not only emphasize foreign cultural teaching but also emphasize the 
synchronization of foreign culture and native culture. Beyond that, we can create good learning cultural atmosphere by set up cultural characteristic education system. Meanwhile, we should further adjust the traditional English evaluation mechanism, make students find their problems and defects existing in their study. With the development of "the Belt and Road Initiative", English will inevitably be more and more important. As the base for talent cultivation, colleges should be more emphasis on English teaching and encourage students to combine their professional knowledge and English study in order to lay a talent foundation for the long-term development of our country.

\section{References}

[1] W.D Liu. "the Belt and Road Initiative": Lead Inclusive Globalization, J. Bulletin of Chinese Academy of Sciences, (2017) No. 4, p212. (In Chinese)

[2] J.Y Feng. Explore the Practical Application of Cross-cultural Communication In the College English Teaching, J. Journal of Jiamusi Vocational College, Vol. 25 (2017) No. 2, p175.

[3] C.Y Bi. Discussion on the Infiltration and Cultivation of Cross-cultural Consciousness in College English Teaching, J. The Guide of Science \& Education, (2017) NO. 1, p208.

[4] H.Y Yang. Cultural Implantation in the College English Teaching from the Perspective of the Difference Between the Chinese and Western Tea Culture, J. Tea in Fujian,Vol.39 ( 2017) No. 2, p337. (In Chinese) 